\title{
THE WAHID INSTITUTE DAN PLURALISME DI INDONESIA (2004-2008)
}

\author{
Syifa Ainun Lutfiana ${ }^{1}$, Kurniawati $^{1}$, R. Wisnubroto ${ }^{1}$, Reni Wulandari ${ }^{1}$ \\ Universitas Negeri Jakarta ${ }^{1}$ \\ Email: syfainunn@gmail.com, kurniawati204@gmail.com, \\ rwisnubroto@unj.ac.id, reniwulandari3105@gmail.com
}

\begin{abstract}
This study discusses the birth and development of The Wahid Institute from 2004 to 2008. The method used in this study is the historical method and the presentation of research results is carried out in the form of descriptive narrative. The results of this thesis study explained that the birth of The Wahid Institute in 2004 was inseparable from Abdurrahman Wahid, Zannuba Ariffah Chafsoh Wahid, Greg Barton, and Ahmad Suaedy who were the initiators of The Wahid Institute. Then there are the founding factors of The Wahid Institute such as social and religious conditions in the post-New Order era, because they were released from the New Order era. because of differences in views, beliefs, culture, and ethnicity. This is due to the lack of pluralism in society, so The Wahid Institute was designed by the initiators to fight for pluralism as expected by Gus Dur.
\end{abstract}

Keywords : Abdurrahman Wahid, The Wahid Institute, Pluralisme.

\section{Abstrak}

Penelitian ini membahas mengenai lahir dan berkembangnya The Wahid Institute dari tahun 2004 sampai tahun 2008. Metode yang digunakan dalam penelitian adalah metode sejarah dan penyajian hasil penelitiannya dilakukan dalam bentuk deskriptif naratif. Hasil penelitian ini menjelaskan bahwa lahirnya The Wahid Institute pada tahun 2004 tidak terlepas dari Abdurrahman Wahid, Zannuba Ariffah Chafsoh Wahid, Greg Barton, dan Ahmad Suaedy yang menjadi inisiator The Wahid Institute. Kemudian ada faktor berdirinya The Wahid Institute seperti keadaan sosial dan keadaan keagamaan pada saat pasca Orde Baru, karena terbebas dari masa Orde Baru banyak bermunculan gerakan Islam yang sebagian menggunakan kekerasan dalam bertindak biasa disebut Islam radikal, dan juga bermunculan kekerasan antar agama di Indonesia yang disebabkan karena perbedaan pandangan, keyakinan, kebudayaan, dan suku. Hal ini dikarenakan kurangnya sikap pluralisme antara masyarakat, karenanya The Wahid Institute dirancang oleh para inisiator untuk memperjuangkan pluralisme seperti harapan Gus Dur.

Kata kunci : Abdurrahman Wahid, Wahid Institute, Pluralisme. 


\section{PENDAHULUAN}

Indonesia terdiri dari berbagai macam suku dan budaya, keanekaragaman suku dan budaya ini memperkaya Indonesia dalam bingkai kebhinnekaan ini merupakan kelebihan dari negara Indonesia karena mampu mewadahi beragam kebudayaan tersebut, serta mampu bersatu dengan adanya perbedaan yang ada. Di Indonesia terdapat 6 agama yang sudah diakui, yakni: (1) Islam, (2) Protestan, (3) Katolik, (4) Hindu, (5) Buddha, (6) Khonghucu.

Dalam tiap-tiap agama yang diakui di Indonesia ini memiliki keunikan dan adat istiadat, meskipun keunikan dan keberagaman ini menjadi corak kekayaan dari Indonesia dalam pandangan dunia luar, tetapi didalam masyarakat secara horizontal tanpa disadari bisa saja menimbulkan adanya penilaian atas kebudayaan lain dengan nilai dasar dari budaya mereka sendiri (etnosentrisme), dan jika perbedaan ini dapat menyebabkan ketegangan sosial dalam kehidupan masyarakat Indonesia yang nantinya masyarakat akan timbul diskriminasi ras, agama, dan juga budaya.

Ketegangan ini nantinya akan berdampak buruk untuk masyarakat karena timbulnya etnosentrisme tersebut dan standar sosial yang tidak sesuai, akan ada gesekan antara satu sama lain, seperti munculnya kekerasan untuk membenarkan salah satu kebudayaan dan keyakinan saja. Dengan adanya perbedaan keyakinan serta kebudayaan tersebut Indonesia harus memiliki sikap yang pluralisme dengan dasar Bhinneka Tunggal Ika yang harus ditanamkan agar masyarakat satu sama lain mampu menerima perbedaan untuk menjaga keutuhan negara Indonesia, dengan hal ini akan tercipta kedamaian di Indonesia dengan sikap pluralisme, toleransi dan saling menghargai. 
GOURNAL of SOCIAL SCIENCES \& HUMANITIES "ESTORIA" UNIVERSITAS INDRAPRASTA PGRI

Dalam konsep pluralisme bangsa Indonesia yang beraneka ragam ini mulai dari suku, agama, ras, dan golongan dapat menjadi bangsa yang satu dan utuh. Sedangkan ketika membicarakan teologi hanya menyentuh pada aspek ketuhanan saja, akan banyak sekali tindakan yang mengatasnamakan Tuhan, tetapi praktek dan dampaknya justru menodai nilai-nilai kemanusiaan. Maka dari itu, Gus Dur memformulasikan konsep iman tidak hanya dalam domain ketuhanan saja, tetapi juga dalam domain kemanusiaan. Hal ini berkaitan erat dengan konsep hak asasi manusia dan pluralism sebagai kenyataan bahwa Indonesia beragam (Syarkun, 2013).

Meskipun di Indonesia sudah dikenal sebagai bangsa yang toleran, masih saja ada tindakan diskriminasi terhadap salah satu keyakinan. Hal ini dapat dilihat dari masih adanya keributan antara pemeluk agama, etnis dan lain-lain. Seperti yang tercatat dalam laporan kebebasan beragama yang ditulis dan ditebitkan oleh Wahid Institute pada tahun 2008 adanya tindak kekerasan terhadap pemeluk agama Hindu di Lombok, NTB. Perusakan Pure Sangkareang yang telah berdiri puluhan tahun di Kecamatan Narmada, Lombok Barat, NTB dilakukan oleh warga muslim setempat, karena adanya kecurigaan dari warga sekitar jika perbaikan Pure Sangkareang ini bertujuan untuk menjadikannya pure terbesar di Lombok (Institute, 2008). Hal ini mengakibatkan kerugian bagi pemeluk agama Hindu di Lombok. ini menunjukan bahwa Indonesia masih kurang meneladani sikap pluralisme. Pluralisme yang dimaksud adalah gagasan-gagasan yang dilontarkan Abdurrahman Wahid dalam upaya menyikapi pluralitas masyarakat dengan perbedaan budaya, agama, etnik, bahasa, warna kulit dan ideologi dari manusia satu dengan yang lainnya.

Lembaga Wahid Institute diresmikan pada 7 September 2004 dalam rangka melaksanakan gagasan-gagasan Abdurrahman Wahid The Wahid Institute dan Pluralisme di Indonesia (2004-2008) | 211 
(Gus Dur) mengenai pluralisme. Lembaga ini didirikan untuk mempromosikan sikap menerima keberagaman agama, suku, ras, dan sebagainya yang ada di Indonesia dan memperluas nilai-nilai perdamaian serta menanamkan sikap anti kekerasan di Indonesia untuk mencapai negara yang penuh rasa damai. Lembaga yang diinisiasi oleh Abdurrahman Wahid, Zannuba Ariffah Chafsoh Rahman Wahid atau yang akrab dipanggil Yenny Wahid anak dari Gus Dur, Greg Barton (penulis buku Biografi Abdurrahman Wahid), dan Ahmad Suaedy.

Pendirian lembaga ini diharapkan oleh Abdurrahman Wahid (Gus Dur) dapat membangun pemikiran Islam moderat yang akan mendorong terciptanya pluralisme beragama. Dalam peresmiannya Gus Dur mengatakan bahwa putrinya, Yenny Wahid yang mendorong terbentuknya lembaga ini. Yenny selaku direktur

utama The Wahid Institute dalam acara peresmian mengatakan bahwa "Tujuan Wahid Institute sejalan dengan visi Gus Dur yaitu membangun pemikiran Islam moderat yang mendorong terciptanya demokrasi pluralisme agama-agama, multikulturalisme, dan toleransi dikalangan kaum muslim Indonesia”. Hal ini berkenaan dengan data akta pendirian lembaga yang diterbitkan tanggal 27 Agustus 2003 di dalamnya tertulis bahwa lembaga ini "Yayasan Lembaga Abdurrahman Wahid" yang sekarang kita kenal Wahid Institute ini memiliki maksud dan tujuan yang tertulis di dalam akta, yaitu:

“(1) sebagai wadah atau lembaga yang dapat mensosialisasikan, melestarikan, dan mengimplementasikan pemikiran-pemikiran Abdurrahman Wahid terutama tentang Islam, Demokrasi dan Pluralisme. (2) membangun dan memperkuat jaringan, baik nasional maupun internasional untuk Islam, Demokrasi, dan Pluralisme."

212 | ESTORIA Volume 2, No. 1, Bulan Oktober Tahun 2021 
¿ JOURNAL of SOCIAL SCIENCES \& HUMANITIES "ESTORIA" UNIVERSITAS INDRAPRASTA PGRI

Lembaga ini memiliki fokus dalam kegiatan sosial untuk terciptanya visi Gus Dur mengenai Demokrasi, Islam moderat, dan Pluralisme. Dalam tujuannya Wahid Institute pun menjalankan kegiatan-kegiatan untuk mencapai tujuan tersebut seperti yang tertulis di dalam akta pendirian, (1) kajian, (2) penelitian (3) pendidikan (4) media dan penerbitan (5) pengembangan masyarakat. Fokus lembaga Wahid Institute adalah menyuarakan isu-isu yang terkait dengan keIslaman, demokrasi, dan pluralisme untuk membawa Indonesia menjadi negara yang jauh dari sikap diskriminasi, kurangnya menerima perbedaan dan kekerasan atas nama agama. Mengingat Gus Dur pun sudah dikenal dengan perjuangannya terhadap isu-isu keagamaan.

Di Indonesia dalam sejarahnya memiliki keterkaitan dengan budaya, keyakinan, dan keberagam karena masyarakat memiliki kebebasan untuk berbudaya dan berkeyakinan hal ini dikuatkan dengan Undang-Undang Dasar 1945 Pasal 28 E yang menegaskan kebebasan untuk memeluk agama dan beribadah sesuai agama yang dianutnya serta jaminan perlindungan dari negara terhadap segala bentuk diskriminasi. Adanya kebebasan memeluk agama dan keyakinan ini membuka ruang perbedaan di antara masyarakat di Indonesia, perbedaan tidak menjadi alasan akan adanya konflik horizontal yang mengatasnamakan agama untuk menyeragamkan keyakinan yang ada. Pun dalam acara peresmian Wahid Institute, Yenny Wahid mengatakan:

"The Wahid Institute meyakini pembelaan terhadap kemanusiaan merupakan esensi tertinggi dari agama. Agama dihadirkan ke dunia ini untuk membela harkat dan martabat kemanusiaan (agama apapun tidak mempunyai makna jika tidak merefleksikan pembelaan atas kemanusiaan)." (Wahidin Institute, n.d.) 
Dalam menyuarakan pluralisme dan mengatasi konflik yang terjadi pada masyarakat, Wahid Institute mengadakan berbagai kegiatan. Kegiatan yang dilakukan meliputi forum diskusi, seminar, dan dialog, kampanye Islam demokrasi dan pluralisme, monitoring isu keagamaan, dan berbagai kegiatan lain untuk mendorong masyarakat untuk hidup berdampingan antaragama. Gus Dur menaruh harapan untuk Indonesia agar menjaga sikap pluralisme, baginya pluralisme bersifat mutlak untuk membangun Indonesia yang memiliki banyak suku bangsa dan agama (Ubaid \& Bakir, 2015). Sikap pluralisme dianggap penting untuk masa depan masyarakat dalam hidup berdampingan agar tidak mudah tersulut oleh isu-isu agama dan penyeragamaan dalam beragama. Dalam laporan kebebasan beragama di tahun 2008, Wahid Institute menuliskan isu-isu keagamaan di Indonesia yang menyebutkan bahwa kasus lemahnya sikap pluralis juga terjadi saat keyakinan yang dianggap tidak sama, seperti (1) penyesatan terhadap kelompok/individu (2) kekerasan berbasis agama (3) regulasi bernuansa agama (4) konflik tempat ibadah (5) kebebasan berpikir dan berekspresi (6) hubungan antarumat beragama (7) fatwafatwa keagamaan (8) moralitas dan pornografi. Adapun solusi atau rekomendasi dari lembaga Wahid Institute tidak hanya melibatkan salah satu pihak, tetapi semua pihak yang memiliki peran dalam meminimalisir konflik dan isu-isu yang ada di masyarakat, seperti (1) pemerintah (2) aparat penegak hukum (3) partai politik (4) masyarakat.

Tujuan penelitian ini adalah untuk mengetahui perjuangan lembaga dalam melanjutkan perjuangan dalam memperluas gagasan Gus Dur tentang pluralisme di Indonesia serta mengenai kejadiankejadian sesudah terbentuknya Wahid Institute saat situasi sosial, dan politik mengambil andil untuk berbagai kejadian lemahnya sikap pluralisme yang terjadi di Indonesia.

214 | ESTORIA Volume 2, No. 1, Bulan Oktober Tahun 2021 
COUURNAL of SOCIAL SCIENCES \& HUMANITIES "ESTORIA" UNIVERSITAS INDRAPRASTA PGRI

\section{METODE PENELITIAN}

Penelitian ini menggunakan pendekatan metode sejarah dan penyajian hasil penelitiannya dilakukan dalam bentuk desriptif-naratif serta menggunakan metode sejarah lisan. Penelitian deskriptif-naratif yang lebih banyak menguraikan kejadian-kejadian dalam dimensi ruang dan waktu melalui studi kepustakaan dalam pengumpulan data. Penelitian ini menggunakan metode sejarah lisan, catatan interpretasi dari kesaksian lisan mengenai masa lampau baik individu maupun lembaga. Yang berkaitan dengan pengalaman-pengalaman dan aktifitas pada masa lampau dapat dilihat dan dirasakan melalui proses wawancara dengan memunculkan aspek peristiwa sejarah.

Data dan informasi yang digunakan pada peneltian ini menggunakan data primer dan sekender yang diperoleh dari sumbersumber tertulis, seperti arsip, majalah, koran, dan buku-buku terkait yang relevan dengan pembahasan mengenai The Wahid Institute dan Pluralisme di Indonesia (2004-2008).

\section{HASIL PENELITIAN DAN PEMBAHASAN}

Indonesia terdiri dari berbagai macam suku dan budaya, keanekaragaman suku dan budaya ini memperkaya Indonesia dalam bingkai kebinekaan ini merupakan kelebihan dari negara Indonesia karena mampu mewadahi beragam kebudayaan tersebut, serta mampu bersatu dengan adanya perbedaan yang ada. Di Indonesia terdapat 6 agama yang sudah diakui, antara lain (1) Islam, (2) Protestan, (3) Katolik, (4) Hindu, (5) Buddha, (6) Khonghucu.

Dalam tiap-tiap agama yang diakui di Indonesia ini memiliki keunikan dan adat istiadat, meskipun keunikan dan keberagaman ini menjadi corak kekayaan dari Indonesia dalam pandangan dunia luar, tetapi didalam masyarakat secara horizontal tanpa disadari 
bisa saja menimbulkan adanya penilaian atas kebudayaan lain dengan nilai dasar dari budaya mereka sendiri (etnosentrisme), dan jika perbedaan ini dapat menyebabkan ketegangan sosial dalam kehidupan masyarakat Indonesia yang nantinya masyarakat akan timbul diskriminasi ras, agama, dan juga budaya.

Ketegangan ini nantinya akan berdampak buruk untuk masyarakat karena timbulnya etnosentrisme tersebut dan standar sosial yang tidak sesuai, akan ada gesekan antara satu sama lain, seperti munculnya kekerasan untuk membenarkan salah satu kebudayaan dan keyakinan saja.

Dengan adanya perbedaan keyakinan serta kebudayaan tersebut Indonesia harus memiliki sikap yang pluralisme dengan dasar Bhinneka Tunggal Ika yang harus ditanamkan agar masyarakat satu sama lain mampu menerima perbedaan untuk menjaga keutuhan negara Indonesia, dengan hal ini akan tercipta kedamaian di Indonesia dengan sikap pluralisme, toleransi dan saling menghargai.

\section{Gagasan Pemikiran Gus Dur}

Gagasan pemikiran mengenai pluralisme serta toleransi dalam kehidupan bermasyarakat dikalangan Islam tradisional sudah dikenalkan oleh $\mathrm{KH}$ Hasyim Asy'ari yang memberi peran penting dalam bertumbuhnya sikap toleransi dan pluralisme di Indonesia. KH. Hasyim Asy'ari merupakan pendiri organisasi Nahdatul Ulama dan juga kakek dari Gus Dur yang dikenal sebagai seseorang yang memiliki sikap toleransi, hal tersebut dikatakan oleh Gus Dur bahwa KH. Hasyim Asy'ari merupakan pribadi yang selalu toleran kepada masyarakat disekelilingnya. Sikap tersebut mempengaruhi kepribadian Gus Dur menjadi toleran dan bersikap pluralis (Daisaku Ikeda, 2013).

216 | ESTORIA Volume 2, No. 1, Bulan Oktober Tahun 2021 
त. JOURNAL of SOCIAL SCIENCES \& HUMANITIES "ESTORIA" UNIVERSITAS INDRAPRASTA PGRI

Sikap pluralisme di Indonesia tidak hanya untuk menerima perbedaan antar ras, kebudayaan, keyakinan dan lainnya, tetapi untuk menanamkan sikap menghormati antara para pemeluk agama. Maka, pluralisme tidak bisa disebut sebagai penyeragaman, atau menyamakan kedudukan agama, yang harus ditekankan bahwa semua agama memiliki kebaikannya masing-masing bahwa setiap agama harus saling menghargai, menghormati, memahami akan perbedaan yang ada pada masing-masing keyakinan beragama. Sikap pluralisme yang demikian merupakan dasar untuk mewarnai kehidupan ragam suku, agama, ras, dan antargolongan agar tercipta kehidupan masyarakat yang penuh perdamaian.

Kehidupan pluralis yang berjalan di Indonesia bersanding dengan sikap demokratis, dimana sikap pluralis berperan dalam hal menerima suatu perbedaan, memiliki sikap toleransi ataupun kesetaraan. Pluralisme tidak selalu diterima oleh masyarakat atau kelompok masyarakat, maka dari itu nilai-nilai pluralistik bukan sesuatu yang diberikan begitu saja oleh agama dan negara melainkan harus diperjuangkan. Memperjuangkan pluralisme diperlukan sikap toleransi yang ditanamkan pada kehidupan bermasyarakat, toleransi memiliki dua penafsiran Pertama, penafsiran negative menyatakan bahwa toleransi itu hanya mensyaratkan cukup dengan membiarkan dan menyakiti orang atau kelompok lain. Kedua, penafsiran positif menyatakan bahwa toleransi membutuhkan adanya bantuan dan dukungan terhadapkeberadaan orang atau kelompok lain (Nawawi, 2017).

Keberagaman dalam beragama telah tercantum dalam UUD 1945 yang tertuang dalam UUD 1945 Pasal 29 ayat (1) yang berbunyi: 
(1) "Negara berdasarkan atas Ketuhanan Yang Maha Esa" selanjutnya ditegaskan dalam UUD 1945 pasal 29 ayat (2) yang berbunyi "Negara menjamin kemerdekaan tiap-tiap penduduk untuk memeluk agamanya masing-masing dan untuk beribadah menurut agamanya dan kepercayaannya”.

Kebebasan beragama tertulis dalam UUD 1945 Pasal 28 (e) ayat 1 dan 2 UUD 1945 hasil amandemen disebutkan:

(1) "Setiap orang bebas memeluk agama dan beribadat menurut agamanya, memilih pendidikan dan pengajaran, memilih pekerjaan, memilih kewarganegaraan, memilih tempat tinggal di wilayah Negara dan meninggalkannya serta berhak kembali”. (2) "setiap orang berhak atas kebebasan meyakini kepercayaan, menyatakan pikiran dan sikap, sesuai dengan hati nuraninya”. Hal tersebut ditegaskna lagi dalam pasal 29 (1) "Negara berdasarkan Ketuhanan Yang Maha Esa" (2) "Negara menjamin kemerdekaan tiap-tiap penduduk untuk memeluk agamya masing-masing dan beribadat menurut agama dan kepercayaan itu".

Dengan jaminan dari UUD 1945 Pasal 28 (e) ayat 1 dan 2 UUD 1945 tersebut memperkuat kebebasan beragama dan berkeyakinan pada seluruh masyarakat.

Pluralisme adalah paham yang mengacu kepada kenyataan yang lebih dari satu, dan secara mendasar mencegah adanya pemutlakan, baik dalam pemikiran maupun dalam sikap. Maka, dengan adanya perbedaan secara tidak disadari manusia akan saling menyalahkan dan tidak akan tercipta keharmonisan dalam bermasyarakat. Namun, dengan adanya pemahaman mengenai sikap yang pluralis antara masyarakat dan semua perbedaannya akan menciptakan sikap pluralis yang mampu menerima satu sama lain (Basuni, 2012).

218 ESTORIA Volume 2, No. 1, Bulan Oktober Tahun 2021 
कํ JOURNAL of SOCIAL SCIENCES \& HUMANITIES "ESTORIA" UNIVERSITAS INDRAPRASTA PGRI

Sebelum terbentuknya lembaga Wahid Institute, Gus Dur sebagai presiden telah melakukan berbagai hal untuk mendorong sikap pluralisme karena tampak jelas bahwa salah satu permasalahan yang dihadapinya adalah permasalahan konflik kelompok dan agama. permasalahan antara kelompok masyarakat dan agama ini menyebabkan konflik antar masyarakat mayoritas dan juga minoritas, seperti pada masa orde baru yang pernah terjadi kepada masyarakat Tionghoa yang mengalami tindakan diskriminasi dari pemerintah maupun masyarakat dilingkungannya. Tionghoa yang dianggap bukan orang asli Indonesia terus mengalami diskriminasi. Pada kepemimpinan Soeharto, ia mengeluarkan Instruksi Presiden No. 14 Tahun 1967 yang menyatakan bahwa Perayaan-perayaan pesta agama dan adat istiadat Cina dilakukan secara tidak mencolok didepan umum, melainkan dilakukan dalam lingkungan keluarga (internal). Bagi Gus Dur, konflik-konflik yang sudah terjadi sudah saatnya dianggap selesai apapun alasannya, karena bangsa sudah kuat dan tidak perlu takut pada kelompok manapun. (F.AF., 2012)

Setelah dikeluarkannya Keputusan Presiden No. 6 Tahun 2000, Gus Dur menindaklanjuti pencabutan Instruksi Presiden No. 14 Tahun 1967 dengan menerbitkan Keputusan Presiden No. 19 Tahun 2001 tanggal 9 April 2001 yang meresmikan Imlek sebagai hari libur fakultatif (hanya berlaku bagi mereka yang merayakannya) yang bertujuan untuk mengajak segenap rakyat Indonesia untuk mau menghargai perbedaan (No, 14AD). Walaupun banyak pihak yang mengecam keputusan yang dibuat Gus Dur, ia sama sekali tidak membatalkan keputusan tersebut.

Keputusan Gus Dur ini disambut gembira oleh etnis Tionghoa atas kebijakannya ia diberikan sebutan sebagai Bapak Tionghoa The Wahid Institute dan Pluralisme di Indonesia (2004-2008) | 
Indonesia. Keputusan Gus Dur tentang pencabutan Instruksi Presiden No.14 Tahun 1967 yang berisi pelarangan perayaanperayaan pesta agama dan adat istiadat Cina dan hanya membolehkan perayaan dilingkungan keluarga saja, dan menerbitkan Keputusan Presiden No. 19 Tahun 2001 tanggal 9 April 2001 yang meresmikan Imlek sebagai hari libur fakultatif. Dinilai berbeda dari masyarakat mayoritas di Indonesia merupakan tindakan tidak menghargai dan menerima perbedaan, dengan ini inisiator Wahid Institute merancang lembaga sebagai wadah untuk mengedukasi masyarakat untuk lebih menghormati perbedaan dan tidak melakukan kekerasan ataupun diskriminasi kepada masyarakat minoritas. Dengan begitu akan tercipta keharmonisan dan sikap pluralisme di Indonesia.

Pluralisme pada dasarnya kelanjutan dari sikap toleransi moral dan koeksistensi. Jika sikap toleransi itu adalah kebiasaan menghargai perbedaan sekedarnya dipermukaan, sementara koeksistensi adalah menerima eksistensi pihak lain, tetapi tidak mengekang munculnya konflik. Sementara pluralisme ialah, semangat untuk saling melindungi, mengabsahkan kesataraan, dan mengem-bangkan rasa persaudaraan di antara sesama manusia baik itu sebagai pribadi maupun kelompok. Di samping itu pula, semangat pluralisme mengedepankan kerja sama demi membentuk nilai-nilai kemanusiaan universal, dan memberikan kesempatan yang sama terhadap pihak lain terutama hak-hak sipilnya atas nama warga bangsa, maupun warga dunia (Wibisono, 2016).

\section{Tokoh Inisiator Wahid Institute}

Tokoh yang dianggap mewakili pemikiran pluralisme di Wahid Institute yakni Abdurrahman Wahid (Gus Dur) yang memperjuangkan berbagai permasalahan dalam konteks pluralisme 
hingga di tahun 2004 hingga ia mendirikan lembaga Wahid Insititute untuk mengkampanyekan sikap pluralisme dalam kehidupan masyarakat di Indonesia. Dalam dialognya Gus Dur mengatakan ingin semua agama hidup berdampingan. Pada suatu kesempatan Gus Dur menyatakan: "Saya mendorong hidup berdampingan antaragama dan prinsip multi-budaya lewat berbagai kegiatan The Wahid Institute." (Daisaku Ikeda, 2013).

Selain Gus Dur, Yenny Wahid juga memiliki peranan penting dalam terbentuknya lembaga ini, Yenny Wahid pun memiliki pandangan yang serupa dengan ayahnya mengenai fenomenafenomena yang ada mengenai pluralisme, kemanusiaan, kebebasan beragama, toleransi dan lain sebagainya.

Yenny Wahid melihat bahwa Indonesia yang memiliki beragam agama ini harusnya saling mengasihi, menghormati, dan lain-lain. Namun, ia melihat adanya kasus yang mencoreng perdamaian Indonesia dengan kekerasan yang menyerang individu maupun kelompok dalam kasus yang mengatasnamakan agama tertentu. Seperti kasus dimana agama Islam yang menjadi mayoritas di Indonesia tapi tidak menghormati keberagaman

Selain Gus Dur dan Yenny Wahid, Dr. Gregorius James Barton merupakan salah satu inisiator The Wahid Institute, ia akrab disapa Greg Barton, ia merupakan Guru besar studi Indonesia yang berkebangsaan Australia yang melakukan penelitiannya di Indonesia, ia menulis buku Biografi Gus Dur, dalam menyelesaikan tulisannya tentang Gus Dur, Greg Barton selalu berpergian bersama Gus Dur untuk menuliskan keseharian Gus Dur. Lalu, selain itu salah satu inisiator lainnya adalah Ahmad Suaedy yang dikenal sebagai aktivis Islam progresif di Indonesia yang sudah lama 
berkecimpung didalam dunia perdamaian, pluralisme dan lain sebagainya.

Wahid Institute dirancang para inisiator untuk menjalani hidup berdampingan dengan keyakinan, agama, kebudayaan, maupun suku yang berbeda dan untuk meminimalisir tindakan kekerasan yang dilakukan organisasi masyarakat seperti Hizbut Tahrir Indonesia (HTI) dan Front Pembela Islam (FPI) yang tidak jarang melakukan tindakan kekerasan karena perbedaan pandangan berpikir. Lalu, Para inisiator The Wahid Institute sadar bahwa mereka tidak bisa membiarkan "keyperson" dalam masyarakat ikut masuk kedalam Islam radikal maupun golongan anti demokrasi, dan mereka ingin pemikiran Gus Dur mengenai pluralis, demokrasi, dan toleransi tetap ada walaupun Gus Dur sudah tidak menjadi ketua Pengurus Besar Nahdatul Ulama (PBNU) dan presiden di tahun 1999 dan maka dari itu The Wahid Institute dirancang sebagai sosial control untuk membawa masyarakat umum serta warga NU yang biasa disebut Nahdliyin, anak-anak pesantren yang memiliki paham yang sejalan agar tidak terbawa arus Islam radikal dan menghindari masa anti demokrasi.

Pada tahun 2004 sampai 2005 merupakan awal Wahid Institute berdiri dan diresmikan, pada saat itu Wahid Institute belum melakukan kegiatan secara massif, mereka masih membangun jaringan dibeberapa daerah di Indonesia. Lembaga hanya mengadakan acara workshop yang dihadiri oleh para tokoh masyarakat seperti Kyai dan Nyai dibeberapa daerah serta turut mengundang aktivis muda lokal yang memahami kejadian-kejadian yang berhubungan dengan kasus kurangnya sikap pluralis, intoleransi, hak asasi manusia, hak perempuan dan lain-lain.

222 | ESTORIA Volume 2, No. 1, Bulan Oktober Tahun 2021 
Setelah diadakannya workshop tersebut mereka mengeluarkan tulisan yang berkaitan dengan kasus kurangnya sikap pluralis, intoleransi, dan lain-lain. Dengan maksud untuk mengedukasi masyarakat melalui tulisan agar terhindar dari tindakan tersebut dan mampu hidup rukun dan berdampingan.

Sejak tahun 2006 lembaga mengeluarkan buku yang berjudul Islamku, Islam anda Islam kita Agama Masyarakat Negara Demokrasi, Jakarta: The Wahid Institute, 2006. Pada tahun 2007 Wahid Institute sudah mempublikasikan tulisan mengenai isu-isu dan kasus-kasus mengenai kurangnya sikap pluralis, dan toleransi laporan ini belum ditulis dalam skala tahunan, hanya bulanan saja dan dimulai pada bulan Juli, Agustus, dan Oktober. Sejak tahun 2008 Wahid Institute pertama kali mengeluarkan laporannya dengan judul Laporan tahunan Wahid Institute 2008 pluralisme beragama/berkeyakinan di Indonesia, laporan tersebut dipublikasikan dengan format tahunan yang meneliti setiap kasus ataupun isu yang terjadi selama tahun 2008.

Perkembangan yang dilakukan oleh Wahid Institute dilakukan secara konsisten dengan cara mengeluarkan tulisan hasil-hasil riset serta menerbitkan buku dan laporan terkait hal-hal mengenai kurangnya sikap pluralisme, intoleransi, dan lain-lain. Hal ini merupakan pencapaian untuk Wahid Institute dalam mengedukasi dan menanamkan kesadaran masyarakat akan pentingnya sikap pluralisme dan toleransi untuk keharmonisan hidup berdampingan antara masyarakat di Indonesia.

\section{KESIMPULAN}

Para inisiator menyadari bahwa Gus Dur merupakan contoh bagi masyarakat dalam hidup berdampingan dengan sikap pluralisme, hingga 
terciptanya Wahid institute memberikan gambaran bahwa lembaga ini memiliki peranan sebagai penerus cita-cita Gus Dur mengenai kehidupan masyarakat yang penuh perdamaian. Perdamaian yang dicita-citakan Gus Dur direalisasikan dalam bentuk lembaga yang dirancang dinamai dengan nama Wahid Institute yang memiliki penamaan khas Wahid untuk menunjukan bahwa lembaga tersebut dibuat sebagai untuk mewadahi segala pemikiran serta cita-cita Gus Dur dalam mencapai Indonesia yang penuh perdamaian dengan sikap pluralisme, toleransi dan demokrasi.

Sebagai wadah untuk masyarakat, Wahid Institute memberi edukasi untuk masyarakat melalui website dan laporan tahunannya dikatakan bahwa Wahid Institute akan terus berkomitmen dengan membuat program yang bermanafaat untuk masyarakat seperti seminar, dialog tokoh, monitoring isu keagamaan, membuat perpustakaan umum dan membuat laporan serta buku secara berkala untuk lebih mengedukasi pentingnya sikap pluralisme dalam berkehidupan di Indonesia yang kaya akan agama dan kebudayaan serta pandangan dari masyarakat itu sendiri.

Wahid Insitute melakukan riset untuk mendalami kasus-kasus intoleransi ataupun kekerasan yang terjadi karena adanya perbedaan baik dari pandangan maupun kebudayaan dan keyakinan, riset ini dilakukan untuk melihat di daerah mana saja yang masih minim sikap pluralis dan yang masih banyak melakukan kekerasan atas alasan perbedaan antara masyarakat. Di Indonesia tercatat ada beberapa kasus yang merupakan konflik horizontal yang terjadi kepada masyarakat, halhal yang menjadi pemicu adanya konflik bisa disebabkan oleh masalah perbedaan yang berkaitan dengan suku, agama, ras dan antargolongan. Indonesia yang memiliki keberagaman bisa saja bersinggungan antara satu dan lainnya mengenai isu SARA, ketegangan sosial yang terjadi atas

224 | ESTORIA Volume 2, No. 1, Bulan Oktober Tahun 2021 
perbedaan ini bisa menyebabkan pandangan yang menilai bahwa suku atau agama yang mereka yakini bahwa hanya suku dan agamanya saja yang dianggap benar, walaupun perbedaan SARA menjadi salah satu pemicu timbulnya konflik ada pula pemicu lain yang bisa menyebabkan konflik horizontal semakin memburuk, seperti kesenjangan ekonomi, ketegangan politik, dan lain sebagainya.

\section{DAFTAR PUSTAKA}

Basuni, A. (2012). Aktualisasi pemikiran pluralisme KH> Abdurrahman Wahid. Sekolah Pascasarjana Universitas Islam Negri (UIN) Syarif Hidayatullah Jakarta.

Daisaku Ikeda, K. H. (2013). Dialog peradaban untuk toleransi dan perdamaian. Gramedia Pustaka Utama.

Institute, L. T. T. W. (2008). Pluralisme Beragama/Berkeyakinan di Indonesia: Menapaki Bangsa yang Kian Retak.

Instruksi Presiden No. 14 Tahun 1967.

Keputusan Presiden No. 19 Tahun 2001.

Keputusan Presiden No. 6 Tahun 2000.

Nawawi, M. (2017). Pluralisme dalam Bingkai Islam dan Negara. IN RIGHT: Jurnal Agama Dan Hak Azazi Manusia, 3(2).

No, I. (14AD). tahun 1967 tentang agama. Kepercayaan Dan Adat Istiadat Cina.

Syarkun, M. (2013). Ensiklopedi Abdurrahman Wahid Jilid 1. Jakarta: PPPKI, Gedung Perintis.

Ubaid, A., \& Bakir, M. (2015). Nasionalisme dan Islam Nusantara. Penerbit Buku Kompas.

Wibisono, M. Y. (2016). Pluralisme Agama dan Perubahan Sosial dalam Perspektif Islam. Prodi Studi Agama-Agama UIN Sunan Gunung Djati Bandung, 1(1), 12-24. 